Assist. Prof. Servet KARDES'

Original scientific paper

Van Yüzüncü Yıl University

UDC: 37.061

Cansu DOKUMACI

graduate student at Van Yüzüncü Yıl University Educational Sciences

DOI: $10.5937 /$ IstrPed2102625K

\title{
THE EFFECT OF MEDIA COMMUNICATION TOOLS ON CHILDREN DURING THE COVID-19 PANDEMIC
}

\begin{abstract}
The negativities experienced during the Covid 19 pandemic process had an impact not only on families but also on children. In this process, to eliminate the negativities in the field of education, distance education has been directed and online learning has become even more important. The use of media communication tools used for online learning has become widespread. This study aims to reveal the effect of media communication tools on children during the pandemic period with the views of families. It was carried out in accordance with the qualitative research approach. The case study technique was used as the research design. The study group of the research consists of 35 parents who have preschool children. Data were collected from the participants through a semi-structured interview form and the collected data was analyzed through content analysis. As a result of the research, it was revealed that the duration of use of media tools by parents and children increased with the pandemic. Parents stated that they generally found themselves competent in using media tools to support their children's education during the pandemic process. It turns out that parents often use media for news, social media and, research. It was concluded that children mostly use media for education, playing games and, watching cartoons. Finally, parents generally think that media tools are used efficiently in the education process of children. As a suggestion, informative broadcasts about the use of media by children and parents and media-based intervention programs for parents and children in early childhood can be recommended.
\end{abstract}

Key Words : Early childhood, media, pandemia, covid 19, parents.

\section{Introduction}

Coronavirus disease (COVID-19) that broke out in Wuhan/China at the end of 2019 has been classified as a pandemic by the World Health Organization (WHO) On March 11, 2020 (Cucinotta \& Vanelli, 2020; WHO, 2020b). Spreading worldwide rapidly, the COVID-19 pandemic has become a global health problem inflicting millions of people (fever, cough, shortness of breath, etc.) and causing tens of thousands of deaths. A pandemic is defined as a global epidemic occurring in many countries or continents and usually affecting a large number of people (Turkish Ministry of Health, 2020).

While healthcare professionals have worked tirelessly to fight the pandemic since its onset, states have taken numerous measures (lockdowns, quarantine, social distancing, etc.) to prevent the spread of the virus (Jason et al., 2020; Wilder-Smith \& Freedman, 2020).

\footnotetext{
1 servetkardes@yyu.edu.tr kardesservet@gmail.com
} 
Governments have also closed down schools to protect public health (Friedman, 2020). However, school closures have disrupted education, inequality in access to digital learning platforms, pressure on schools, and social isolation (UNESCO, 2020). Research shows that lockdowns have a wide range of adverse psychological effects, including stress, confusion, and anger (Akat \& Karatas, 2020; Bozkurt et al., 2020; Liu, Bao, Huang, Shi \& Lu, 2020; Orru et al., 2020; Pfefferbaum \& North, 2020; Pierce et al., 2020; Xiong et al., 2020). People have also been suffering from the fear of contracting the virus, and disappointment, boredom, too little information, and financial losses since the beginning of the pandemic (Brooks et al., 2020). It is only natural that we all experience sensations of worry, fear, and even panic about our lives and those of loved ones (National Ministry of Education, 2020). However, it is of utmost importance that we use constructive ways to express our negative emotions.

Governments have taken measures of varying severity to combat the pandemic but enforced school closures in the strictest way possible (Kawano \& Kakehashi, 2015; Cucinotta \& Vanelli, 2020). The Turkish Ministry of Health announced the first confirmed case of COVID-19 on March 11,2020 , and ordered the closure of schools on March 16, 2020. The Council of Higher Education ( $\mathrm{CHE}$ ) took swift action and shifted to distance education on digital platforms as of March 23 to keep the education continuous and unaffected by the pandemic. Face-to-face education has been largely suspended, and local and central exams have been postponed or replaced by webbased exams. In short, all face-to-face education in Turkey has shifted to distance education. Despite some problems, it has been successful at almost all levels (universities, high schools, secondary schools, and even primary schools). Although it has been problematic for early childhood education (Can, 2020), authorities have addressed some of the problems and managed to integrate preschoolers into distance education. The show called "Activities for the Whole Family" aired on TRT EBA (educational content network by the national television channel) allows preschoolers to participate in distance education from different corners of Turkey. The advances in web-based distance education during the pandemic have made media communication tools (MCTs) all the more important.

Media communication tools (MCTs) allow people to access information wherever they are and whenever they want (Shehata \& Stromback, 2014). Today, even children under the age of two use MCTs (Vandewater et al., 2007). Parents let their children spend time on MCTs to do chores or have some time to themselves before bedtime (Kabali et al., 2015). Media communication tools have become more important for distance education during the pandemic (Sari \& Nayir, 2020). When used the right way, they can promote children's learning and development (Donohue \& Schomburg, 2017). Lestari and Gunawan (2020) argue that distance education makes learning more effective, quality, and fun for preschoolers. However, the pandemic causes fear, anxiety, depression, aggression, and sleep disorders in children because it receives wide media coverage (conventional and digital) imbued with misinformation (van Dijck \& Alinead, 2020; Ostrov, Gentile \& Mullins, 2013; Rapoport, Milanaik, Muthiah \& Adesman, 2019; Ravindran et al., 2020).

Children who are out of school due to the pandemic experience social, emotional, and psychological problems (Miller, 2020). During lockdowns, people spend more time on MCTs to keep up with the latest news on the pandemic and play games, text friends, and watch shows online. However, this adversely affects their short and long-term well-being (Galea, Merchant \& Lurie, 2020; McCrae, Gettings \& Purssell, 2017; Watson, 2020; Yao, 2020; Sun et al., 2020).

Children are eager to learn by doing and living through active interaction with nature and others. However, this need remains unmet due to the preventive measures for the pandemic. Staying indoors too long and hearing such things as "Stay Home, Stay Safe" also affect 
children's physical and mental health. Besides, distance education makes students and parents spend more time on MCTs. The more time they spend on MCTs, the more exposed they are to the news on the pandemic, resulting in fear, anxiety, anger, anxiety, sadness, and guilt (Boelen \& Spuij, 2013). The World Health Organization (2020a) also recommends less exposure to news on the pandemic for lower anxiety and stress levels.

There is a large body of research investigating the effects of pandemics on education (Balci, 2020), parents' views on childhood fears during the pandemic (Alisinanoglu, Karabulut \& Turksoy, 2020), parents' views on home activities during the pandemic (Mart \& Kesicioglu, 2020), the pandemic and its pedagogical repercussions, and open and distance education in Turkey (Can, 2020). However, there is no published research investigating the effects of MCTs on preschoolers during the pandemic. Therefore, this paper looked into the effects of MCTs on preschoolers during the pandemic and sought answers to the following questions:

- $\quad$ Do parents and preschoolers spend more time on MCTs during the pandemic than before?

- $\quad$ Do parents consider themselves competent in using MCTs? What problems do they experience when using them?

- $\quad$ For what purposes do parents and preschoolers use MCTs most?

- How do preschoolers react to news about the pandemic on MCTs?

- What do participants suggest parents or teachers do to use MCTs more efficiently and for education purposes?

\section{METHOD}

\section{Research Design}

This qualitative study focused on parents' opinions about the effects of MCTs on children during the pandemic. Qualitative research allows the researcher to participate in the process and approach participants' experiences, mindsets, views, and statements from a relatively flexible and broad angle (Buyukustun, 2011). A case study is a descriptive analysis design used to explore a particular group's views and experiences on a phenomenon within its own reality and in a certain period (Yin, 2009). The case study was the research design of choice because it allowed us to investigate the effects of MCTs on children. In other words, the case of this study was that the pandemic causes parents and preschoolers to spend more time on MCTs.

\section{Study Group}

Participants were recruited using maximum variation sampling, which is a purposive sampling method. Maximum variation sampling allows the researcher to draw a sample with diverse experiences in line with the research purpose (Yildirim \& Simsek, 2011). The sample consisted of 35 parents ( 20 women; 15 men). The inclusion criteria were: (1) having preschooler children, (2) having different educational backgrounds and jobs, (3) living in different cities of Turkey, and (4) being eager to share their experiences. Of participants, two had a high school degree, five had an associate's degree, 21 had a bachelor's degree, six had a master's degree, and one had a Ph.D. Six participants were 25-30 years of age, 16 were 31-35 years of age, ten were 3640 years of age, and three were $41-45$ years of age. Eleven participants were teachers, five were executives, five were healthcare professionals, two were academics, and ten had other jobs. Six participants had only one child, 25 had two children, and four had three children. 


\section{Data Collection Tools}

The research was approved by a social and humanities ethics committee. The researchers interviewed the participants within a month in the fall semester of 2019-2020. They conducted a literature review and developed a semi-structured interview form, which was the data collection tool of choice because it provides room and flexibility to obtain original and unexpected data (Wilson, 2014). The form consisted of 11 items (expect items on demographic characteristics). The researchers consulted three experts for the relevance and intelligibility of the items. The experts rated the items on a scale of 1 to $3(1=$ relevant, $2=$ not relevant, $3=$ in need of revision). The researchers then revised the items (none removed), especially the items on demographic characteristics, and finalized the form.

A pilot study was conducted with three parents to check the relevance and comprehensibility of the form. One of the participants asked what we meant by "media communication tools." Therefore, before the interviews, the researchers explained to all participants that "media communication tools" referred to the T.V., smartphone, tablet, desktop computer, and laptop. As for the question "What are your suggestions that children use MCTs more efficiently and for educational purposes?," another participant asked the researchers to be clearer as to whom they were asked to make suggestions; to teachers or parents. Therefore, the researchers modified the question to make it more straightforward. After the pilot study, they went over the items and finalized the form.

\section{Data Collection and Analysis}

The researchers held all interviews over the phone due to the pandemic and nationwide preventive measures. Collecting data online also allowed them to achieve maximum sample diversity. They informed all participants about the research purpose and procedure and told them that they could withdraw from the study at any stage and that the data would be used only for scientific purposes and would not be shared with third parties. The researchers obtained informed consent from all participants but one to audio-record the interviews. During the interviews, they asked probing questions to encourage participants to clarify and elaborate on their views. They then listened to the audio records over and over again and completed the interview forms. The participants in the pilot study were not included in the main study.

The data were analyzed using axial and open coding (Corbin \& Strauss, 2008). First, the researchers used a dictation software program to transcribe the interviews ( 99 pages and 28,637 words in total). Each researcher $(n=2)$ read the interviews independently and took notes, and then developed codes. They read the codes over and over again and then sorted and grouped them under high-order conceptual categories. They then discussed them and determined some shared points. Moreover, they used direct quotations in the "Results" section to corroborate their interpretations and inferences. Some of the codes were "The fear of contracting the virus," "Worry," "Shivering," "Talking while asleep," "Waking up suddenly," "Bringing to their games what they see on MCTs," "What is death?," "Where do we go after death?," "Am I going to die, too?," "What will they do after death?," and "I do not want to see my friends." The researchers developed themes based on the frequencies of the codes and the meaning attributed to them. They adopted an iterative process for analysis and kept comparing the codes and themes (Grbich, 1998). They discussed the themes and possible subthemes until they reached a consensus. Afterward, they used Miles and Huberman's formula (1994) [Reliability = (number of agreements) / (number of agreements + number of disagreements)] to calculate interrater reliability, which they found to be $92 \%$, indicating high reliability. 
The researchers showed the forms to participants and told them to point out anything they would like added into or removed from their interviews. The researchers checked the forms of three couples to see if they gave consistent responses about their children. The results showed that their responses were consistent, and therefore, the researchers assumed that all participants gave consistent answers.

\section{RESULTS}

This section addressed the results regarding the effects of MCTs on children during the pandemic.

\section{How Much Time Parents and Their Children Spend on MCTs}

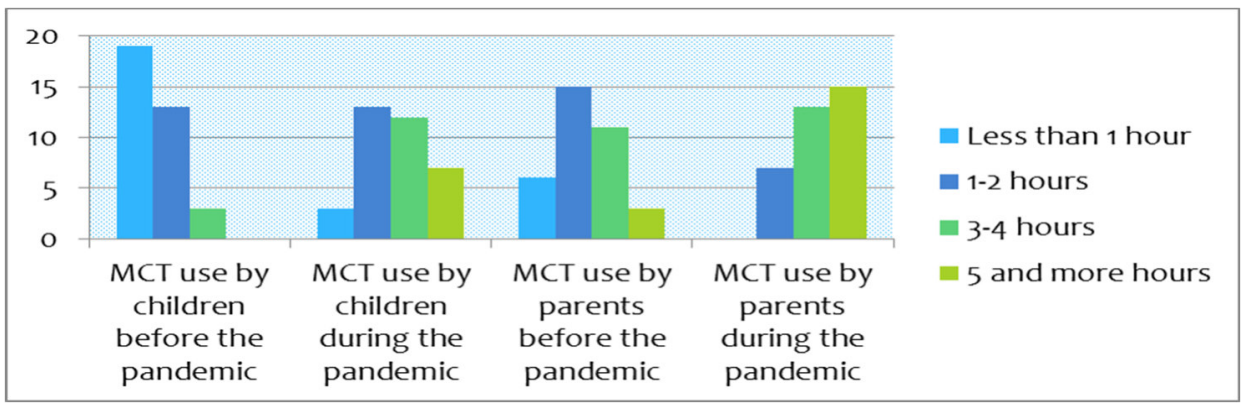

Figure 1: Daily MCT use by parents and children

Before the pandemic, children and parents used to spend about one and two hours on MCTs, respectively. Since the pandemic, children and parents have been spending about three and five hours on MCTs, respectively.

The following are direct quotations from participants:

L.B.: "I used to spend one hour or two on my phone, but now it's about 7-8 hours. It like an addiction, I can't do without it anymore. It's the same for the kids. They are doing what we are doing, besides, it's our bad; I mean, we don't make time for them, and so they end up spending too much time on MCTs..."

H.D.: "... All social media and distance education, our kids are sitting in front of the T.V. or they are always on their phones or tablets... They have become addicted to social media and their computers and tablets."

M.D.: "Anything we do, we do it online now, so we spend more time on MCTs, like three or four hours, sometimes even more."

\section{Parental Competence in MCT Use}

Participants stated that they considered themselves competent in using MCTs to support their children's education, although at first, they had had some difficulty. The following are direct quotations from participants:

E.I.: Yes, I'm definitely an active user.

Ö.O: At first, I was all thumbs, but now I feel competent.

H.N.: I was a newbie in the early days of the pandemic, but now I can Zoom and work online with my students..." 
A.A.: "I don't think I'm that good at using them, but we have an advantage, I mean, my wife is a teacher, and so, it's an advantage, I mean, people around me don't have that. Some of my friends really have a hard time adapting, so I heard. I wish we had some sort of training."

\section{Challenges of MCTs}

Participants had to deal with Internet connection issues, low quality video and sound, too little information, lack of computers, and power shortage. Some parents stated that they did not face any problems. The following are direct quotations from participants:

Ö.G: "Well, for example, we had problems like, disconnection during Zooming, audio sync problems when talking to the teacher, out-of-sync videos, slow Internet and whatnot."

E.B.: "Pop-ups are annoying, but other than that, I haven't had any other problems so far."

B.A.: "I haven't had any particular problem actually. It was just that sometimes EIN was too busy, but I figured it out, I connected to another distance education platform."

M.Z.: "Yes, I had some problems, because the system was too slow..."

F.Ç: "No, I haven't had any problems so far."

\section{Why Parents and Children Use MCTs}

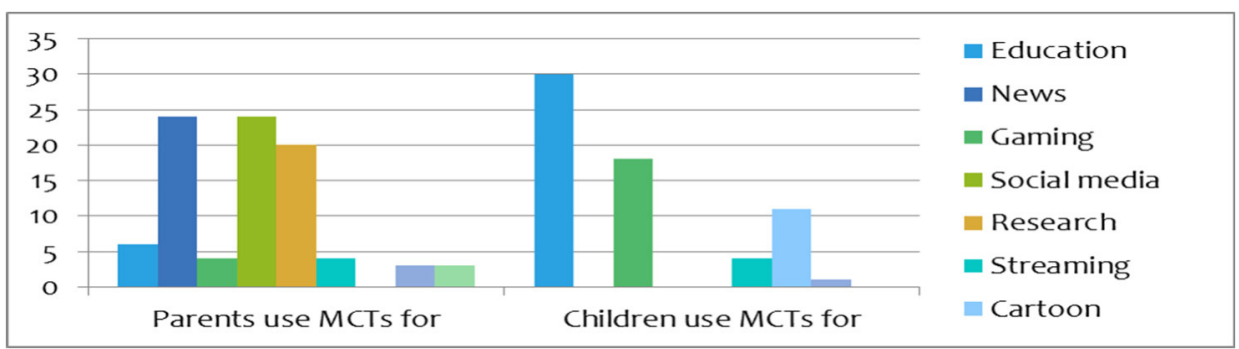

Figure 2: Why Parents and Children Use MCTs

Parents use MCTs to keep up with the news, check social media, and do research. They rarely use them for education, gaming, streaming, communication, and shopping. On the other hand, children use MCTs for education and gaming, streaming cartoons, watching T.V., and talking to their teachers.

\section{Effects of MCTs on Children}

The effects of MCTs on children were grouped under four main themes: (1) emotions evoked by news on the pandemic, (2) reaction, (3) statements, and (4) positive effects of the media. Figure 3 shows the themes, subthemes, and codes. 


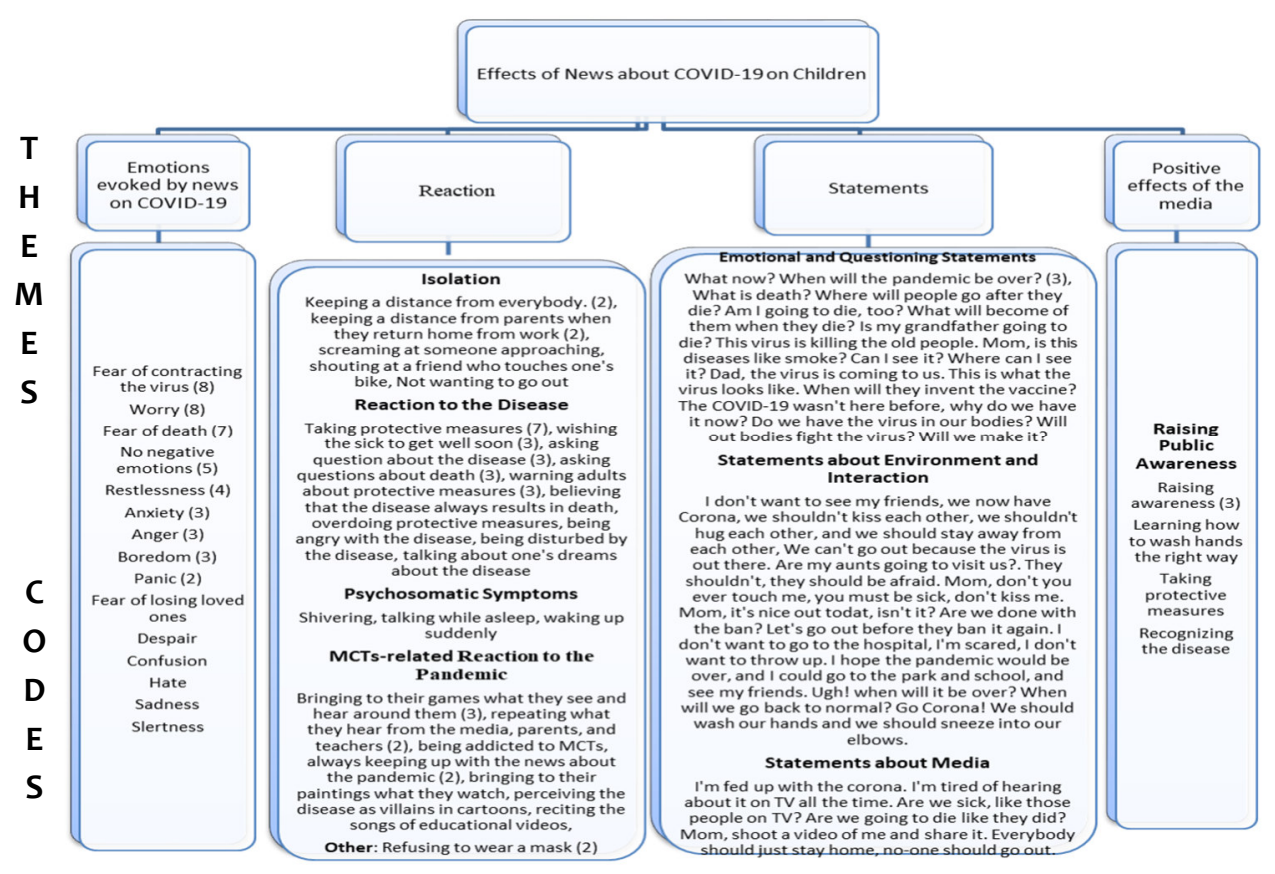

Figure 3: Effects of MCTs on Children

The news about the pandemic makes children worried, restless, nervous, angry, bored, helpless, confused, sad, and alert and makes them afraid of contracting the virus and dying or losing loved ones. Parents stated that children acted out or talked about their emotions. They isolated themselves, wished that the pandemic was over, asked questions about the disease and death, and presented with psychosomatic symptoms (talking while asleep, waking up suddenly, shivering, etc.). They also brought to their games what they saw and heard around them, repeated what they heard from the media, parents, and teachers, kept up with the news about the pandemic, brought to their paintings what they watched, saw the disease as a villain like in cartoons, and recited the jingles of educational videos.

The results suggested that children's reaction to the pandemic was affected by the media (news, advertisements, social media, videos, phone calls, cartoons) and the social setting (parents, teachers, friends, etc.)

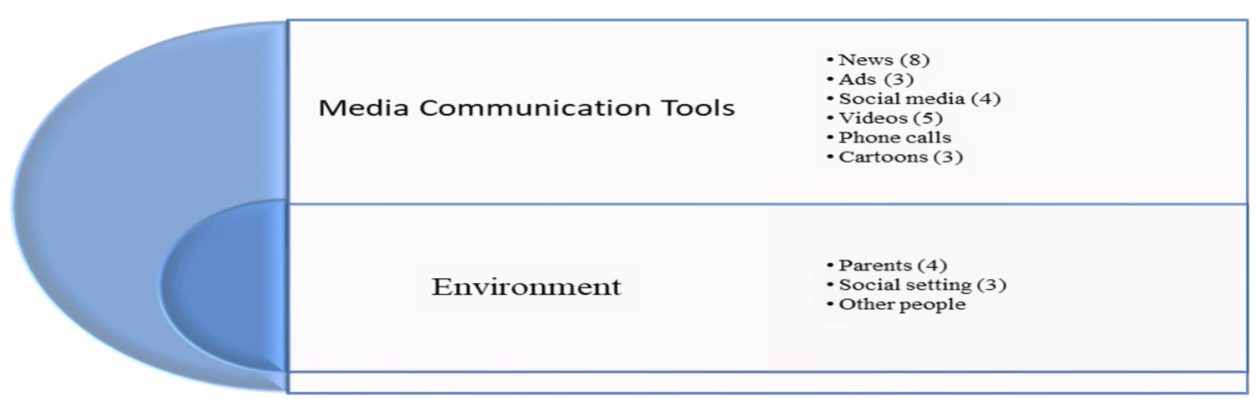

Figure 4: Causes of Children's Reaction to the Pandemic 
The following are direct quotations from participants:

Ö.G: "We think that our kid has been a little obsessed with the measures after he saw all the news about the pandemic on MCTs. He thinks that he's going to be sick or infect us with the virus or hurt his little brother. When someone goes up to him, he bursts with anger and shouts and runs away... When he hears the death toll or about people who died from the virus, he asks questions like 'What is death?,' 'What do they do to the body when someone dies?,' 'Where do people go after they die?,' 'Am I going to die, too?,' or 'Are you going to die, or me?'..."

H.A.: "... To our regret, we used to turn on the T.V. and watch the news, like how many people tested positive for COVID-19 that day, how many died, etc. We became kind of obsessed with it, and so, the kids became restless..."

\section{Participants' Suggestions for Using MCTs for Educational Purposes}

Participants' suggestions for using MCTs for educational purposes were grouped under the themes of "suggestions for parents," "suggestions for teachers," and "other." Figure 6 shows the themes, subthemes, and codes.

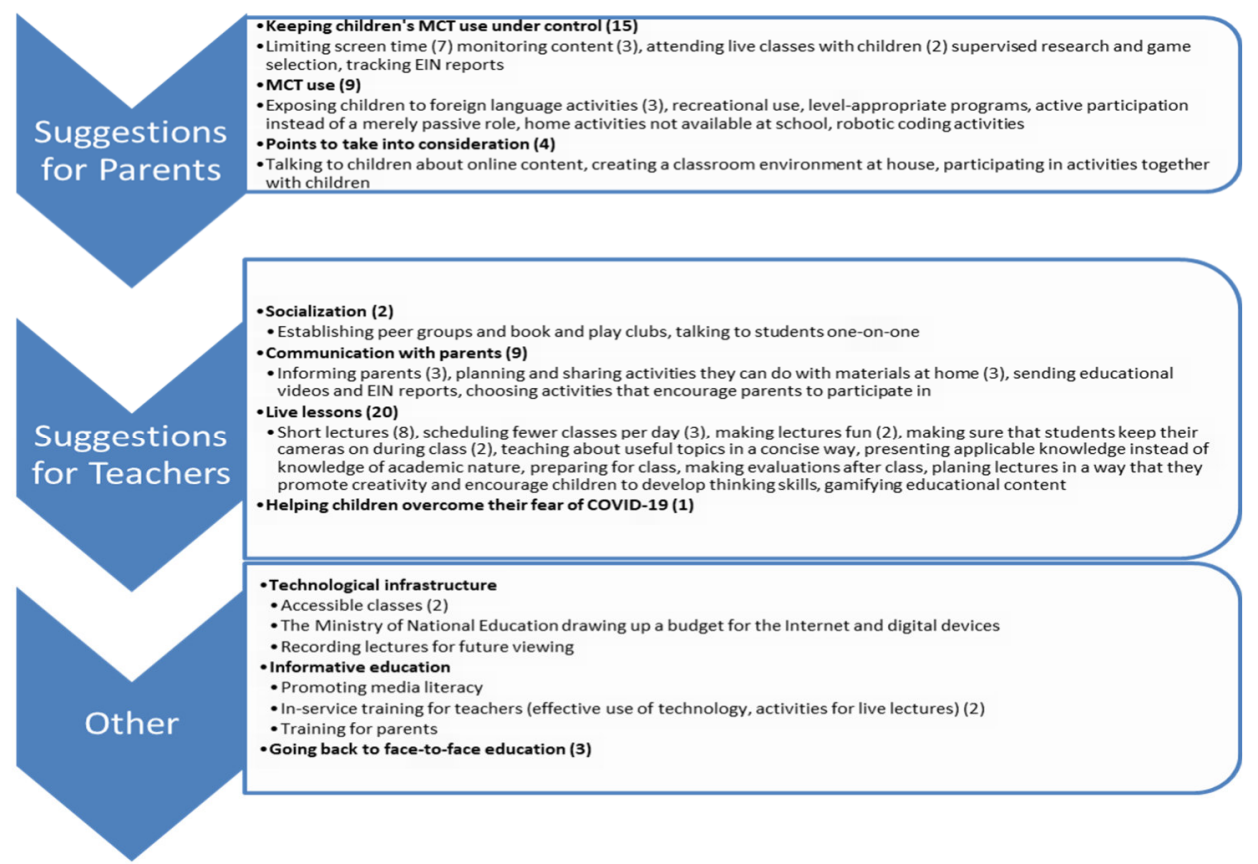

Figure 5: Suggestions for Using MCTs for Educational Purposes

Fifteen participants believed that parents interested in getting their children to use MCTs more efficiently should keep those tools under control. Nine participants had suggestions as to how to use MCTs. They suggested that parents channel their children to foreign language learning, make sure that they use MCTs for fun, and choose activities facilitating active participation. According to participants, parents should encourage their children to do activities they cannot do at school and should introduce them to robotic coding or level-appropriate programs. Lastly, they recommended that parents talk to their children about online content, create a classroom environment at home, and participate in all activities together with their children.

The following are direct quotations from participants: 
E.I.: “... I've had some apps I believe are effective and agree with my kid's personality. For example, we have some very useful apps, like SketchUp, which is a chess app. Parents should download such apps on MCTs and get their kids to use them and spend their time more efficiently. For example, my kid designs beautiful houses and toys on SketchUp. By the way, we're interested in Italian. We watch videos in Italian, so, there are tons of things they can do at home that they can't at school. I love those things, and I suggest other parents download them and get their kids to use them." A.A.: "Well, if they [parents] have time, they should attend their kids' lectures. They should keep their kids under control and create a classroom environment at home.

According to participants, teachers are responsible for forming peer groups and book and play clubs, talking to students in person, developing home activities, telling parents where to find educational content or sending them educational videos, choosing activities that facilitate parental engagement, keeping lectures short and fun, scheduling fewer classes per day, teaching about practical things instead of knowledge of academic nature, preparing for lectures, making an evaluation after each class, planning lectures in a way to promote creativity and encouraging children to develop thinking skills, and gamifying the educational content. The following are direct quotations from participants:

B.H.: "Well, first of all, they should keep the lectures short because kids lose concentration in class if it's too long. The second thing is preparation. Teachers and parents should definitely prepare for class. The third thing is evaluation. I mean, I think that the teacher should make an evaluation of the effectiveness of the lesson or on feedback about an activity she did in class."

K.Ç: "Well, I think that parents and kids should spend more quality time and come up with educational materials together instead of spending too much time on MCTs. Teachers should get them to do that."

Ö.G: "...It would make more sense if teachers would go over more useful and basic stuff in a more concise way. I mean, they should teach practical things rather than stuff of academic nature. They should teach things that would get the kids to do research on things they are curious about..." A.A.: "Media literacy should be more explicitly taught. People should be offered online content and trained in it. First teachers and then parents should be trained in it."

V.B.: ".... I believe face-to-face education to be more effective [than distance education]. So, I can't think of any other way to make it [distance education] more effective."

\section{DISCUSSION and CONCLUSION}

Participants and their children have been spending more time on MCTs since the pandemic began. Keskin and Ozer Kaya (2020) also reported that since the pandemic began, students had been spending about twice as much time on social media platforms and in front of the T.V., which may pose risks for their development. For example, Radesky, Silverstein, Zuckerman, and Christakis (2014) found that problems in early childhood self-regulation skills were associated with high exposure to media content.

Most participants find themselves competent in using MCTs to help support their children's education during the pandemic. The greatest challenges they face are Internet connection issues, low ping, out-of-sync videos, too little information, lack of computers, and power shortage. Although participants do not stress it, the OECD (2020) regards the lack of a specific program for using digital devices in distance education as an important problem. Sari and Nayir (2020) also concluded that teachers lacked the technical and pedagogical know-how of integrating digital devices into education. Therefore, as stated by Kim (2020), undergraduate students should be trained in distance education and school-parent cooperation in online learning. Parents think that they cannot support their children's education because they do 
not know much about online education and consider online education useless as their children lack self-regulation skills (Dong, Cao \& Li, 2020). Bozkurt et al. (2020) argue that motivation affects children's academic performance more than technological infrastructure.

Participants use MCTs mostly to hear the news, check social media, and do research. They rarely use them for education, gaming, streaming, communication, and shopping. On the other hand, their children use MCTs more for education, gaming, and streaming cartoons, watching T.V., and talking to their teachers. The news on the pandemic makes children worried, restless, nervous, angry, bored, helpless, confused, sad, and alert and makes them afraid of contracting the virus and dying or losing loved ones. Since the pandemic began, children have isolated themselves, had more screen time, become more anxious about the disease, and suffered from psychosomatic symptoms. Courtney, Watson, Battaglia, Mulsant, and Szatmari (2020) state that the pandemic has caused despair, fear, anxiety, withdrawal, and depression in children. Tso et al. (2020) also argue that prolonged use of digital devices leads preschoolers to psychosocial problems. Gassman-Pines, Ananat, and Fitz-Henley (2020) found that the pandemic adversely affected parents' psychological well-being. Therefore, we can state that parents with low mental well-being are more likely to have children with psychological problems. As Wagner (2020) maintains, family support is the key to enhancing children's development and well-being (Brown, Doom, Lechuga-Pena, Watamura, \& Koppels, 2020; Richter, Cappa, Issa, Lu, Petrowski, \& Naicker, 2020).

Lastly, parents think that their children use MCTs efficiently, probably because children spend most of their time on MCTs for distance education. However, we believe that children should use them under adult supervision because they spend a considerable amount of time gaming and streaming. According to participants, children should use MCTs under adult supervision, while teachers should schedule one-on-one online meetings with their students, keep in touch with parents, and keep their lectures short. OECD (2020) also states that academic performance is closely related to the teacher-student relationship. This is especially true for children of disadvantaged groups who are deprived of self-learning strategies and parental support. The Executive Committee of the World Organization for Early Childhood Education (OMEP, 2020) highlights that preschoolers should interact with their peers and teachers to meet their emotional needs.

Parents and children should be provided with training in MCTs and media-based intervention programs.

\section{REFERENCES:}

Akat, M., \& Karatas, K. (2020). Psychological Effects of COVID-19 Pandemic on Society and Its Reflections on Education. Electronic Turkish Studies, 15(4), 1-13.

Alisinanoglu, F., Karabulut, R., ve Turksoy, E., (2020). Pandemi surecinde cocukluk donemi korkularina yonelik aile gorusleri. Uluslararasi Beseri Bilimler ve Egitim Dergisi, 6, (14), $547-568$.

Balci, A., (2020). Covid-19 ozelinde salginlarin egitime etkileri. Uluslararasi liderlik calismalari dergisi: Kuram ve uygulama. 3(3), $75-85$.

Boelen, P. A., \& Spuij, M. (2013). Symptoms of post-traumatic stress disorder in bereaved children and adolescents: Factor structure and correlates. Journal of Abnormal Child Psychology, 41(7), 1097-1108.

Bozkurt, A., Jung, I., Xiao, J., Vladimirschi, V., Schuwer, R., Egorov, G., Lambert, S., Al-Freih, M., Pete, J., Olcott, Jr., D., Rodes, V., Aranciaga, I., Bali, M., Alvarez, A. J., Roberts, J., 
Pazurek, A., Raffaghelli, J. E., Panagiotou, N., de Coetlogon, P., Shahadu, S., Brown, M., Asino, T. I., Tumwesige, J., Ramirez Reyes, T., Barrios Ipenza, E., Ossiannilsson, E., Bond, M., Belhamel, K., Irvine, V., Sharma, R. C., Adam, T., Janssen, B., Sklyarova, T., Olcott, N., Ambrosino, A., Lazou, C., Mocquet, B., Mano, M., \& Paskevicius, M. (2020). A global outlook to the interruption of education due to COVID-19 pandemic: Navigating in a time of uncertainty and crisis. Asian Journal of Distance Education, 15(1), 1-126.

Brooks, S. K., Webster, R. K., Smith, L. E., Woodland, L., Wessely, S., Greenberg, N., \& Rubin, G. J. (2020). The psychological impact of quarantine and how to reduce it: rapid review of the evidence. The Lancet, 395, 912-920. doi:https://doi.org/10.1016/S01406736(20)30460-8

Brown, S. M., Doom, J. R., Lechuga-Pena, S., Watamura, S. E., \& Koppels, T. (2020). Stress and parenting during the global COVID-19 pandemic. Child abuse \& neglect, 110, 1-14.

Can, E., (2020). Coronavirus (Covid-19) pandemisi ve pedagojik yansimalari: Turkiye'de acik ve uzaktan egitim uygulamalari. Acıkogretim Uygulamalari ve Arastırmalari Dergisi, 6(2), 11-53.

Corbin, J. \& Strauss, A. (2008). Strategies for qualitative data analysis. SAGE Publications, Inc.

Courtney, D., Watson, P., Battaglia, M., Mulsant, B. H., \& Szatmari, P. (2020). COVID-19 impacts on child and youth anxiety and depression: challenges and opportunities. The Canadian Journal of Psychiatry, 65(10), 688-691.

Cucinotta, D., \& Vanelli, M. (2020). WHO declares COVID-19 a pandemic. Acta Bio Medica: Atenei Parmensis, 91(1), 157-160.

Dong, C., Cao, S., \& Li, H. (2020). Young children's online learning during COVID-19 pandemic: Chinese parents' beliefs and attitudes. Children and youth services review, 118, 105440.

Donohue, C., \& Schomburg, R. (2017). Technology and interactive media in early childhood programs: What we've learned from five years of research, policy, and practice. YC Young Children, 72(4), 72-78.

Dunya Saglik Orgutu. "Coronavirus disease 2019 (Covid-19) Situation Report-97". 2020. Retrived from https://www.who.int/docs/default-source/coronaviruse/situationreports/20200426-sitrep-97- covid-19.pdf?sfvrsn=d1c3e800_2/26.04.2020

Friedman, C. (2020). Students' Major Online Learning Challenges amid the COVID-19 Pandemic. Journal of Pedagogical Sociology and Psychology, 1, 45-52.

Galea, S., Merchant, R. M., \& Lurie, N. (2020). The mental health consequences of COVID-19 and physical distancing: The need for prevention and early intervention. JAMA internal medicine, 180(6), 817-818.

Gassman-Pines, A., Ananat, E. O., \& Fitz-Henley, J. (2020). COVID-19 and parent-child psychological well-being. Pediatrics, 146(4), 1-11.

Grbich, C. (1998). Qualitative research in health: An introduction. Sage Publication.

Jason M. Nagata., Hoda S. Abdel Magid ve Kelley Pettee Gabriel., (2020). Screen Time for Children and Adolescents During the Coronavirus Disease 2019 Pandemic. The Obesity Society, 28(9),1582-1583.

Kabali, H. K., Irigoyen, M. M., Nunez-Davis, R., Budacki, J. G., Mohanty, S. H., Leister, K. P., \& Bonner, R. L. (2015). Exposure and use of mobile media devices by young children. Pediatrics, 136(6), 1044-1050.

Kawano, S., \& Kakehashi, M. (2015). Substantial Impact of School Closure on the Transmission Dynamics during the Pandemic Flu H1N1-2009 in Oita, Japan. PloS one, 10(12), e0144839. https://doi.org/10.1371/journal.pone.0144839

Keskin, M., \& Ozer Kaya, D. (2020). COVID-19 surecinde ogrencilerin web tabanli uzaktan egitime yonelik geri bildirimlerinin degerlendirilmesi. Izmir Katip Celebi Universitesi Saglik Bilimleri Fakultesi Dergisi, 5(2), 59-67. 
Kim, J. (2020). Learning and teaching online during Covid-19: Experiences of student teachers in an early childhood education practicum. International Journal of Early Childhood, 52(2), 145-158.

Lestari, P. A. S., \& Gunawan, G. (2020). The Impact of Covid-19 Pandemic on Learning Implementation of Primary and Secondary School Levels. Indonesian Journal of Elementary and Childhood Education, 1(2), 58-63.

Liu, J. J., Bao, Y., Huang, X., Shi, J., \& Lu, L. (2020). Mental health considerations for children quarantined because of COVID-19. The Lancet Child \& Adolescent Health,4,1-3.

Mart, M., \& Kesicioglu, O. S. (2020). COVID-19 Pandemi Surecinde Ailelerin Evde Oyun Oynamaya Iliskin Gorusleri. Electronic Turkish Studies, 15(4), 945-958.

McCrae, N., Gettings, S., \& Purssell, E. (2017). Social media and depressive symptoms in childhood and adolescence: A systematic review. Adolescent Research Review, 2(4), 315-330.

MEB, (2020). Salgin Hastalik Donemlerinde Psikolojik Saglamligimizi Korumak: Yetiskinler Icin Bilgilendirme Rehberi. Ozel Egitim ve Rehberlik Hizmetleri Genel Mudurlugu.

Miller, E. D. (2020). The covid-19 pandemic crisis: The loss and trauma event of our time. Journal of Loss and Trauma, 25(6), 1-13. doi: 10.1080/15325024.2020.1759217

OECD. (2020). Education disrupted - education rebuilt: Some insights from PISA on the availability and use of digital tools for learning-OECD Education and Skills Today. https://oecdedutoday.com/coronavirus-education-digital-tools-for-learning/

OMEP Executive Committee (2020). OMEP Position Paper: Early Childhood Education and Care in the Time of COVID-19. International Journal of Early Childhood, 52, 119-128.

Orru, G., Ciacchini, R., Gemignani, A., \& Conversano, C. (2020). Psychological intervention measures during the COVID-19 pandemic. Clinical Neuropsychiatry, 17(2), 76-79.

Ostrov, J. M., Gentile, D. A., \& Mullins, A. D. (2013). Evaluating the effect of educational media exposure on aggression in early childhood. Journal of Applied Developmental Psychology, 34(1), 38-44.

Pfefferbaum, B., \& North, C. S. (2020). Mental health and the Covid-19 pandemic. New England Journal of Medicine,383(6), 510-512.

Pierce, M., Hope, H., Ford, T., Hatch, S., Hotopf, M., John, A., ... Abel, K. M. (2020). Mental health before and during the COVID-19 pandemic: A longitudinal probability sample survey of the UK population. The Lancet Psychiatry, 7(10), 883-892.

Radesky, J. S., Silverstein, M., Zuckerman, B., \& Christakis, D. A. (2014). Infant self-regulation and early childhood media exposure. Pediatrics, 133(5), 1172-1178.

Rapoport, D., Milanaik, R., Muthiah, N., \& Adesman, A. (2019). Early Childhood Digital Media Use: Inverse Associations with Sleep Time Consistency and Sleep Duration. Pediatrics, 144(2), 52-53.

Ravindran, S., Channaveerachari, N. K., Seshadri, S. P., Kasi, S., Manikappa, S. K., Cherian, A. V., ... \& George, S. (2020). Crossing barriers: Role of a tele-outreach program addressing psychosocial needs in the midst of COVID-19 pandemic. Asian Journal of Psychiatry, 53, (102351), 1-5.

Richter, L. M., Cappa, C., Issa, G., Lu, C., Petrowski, N., \& Naicker, S. N. (2020). Data for action on early childhood development. The Lancet, 396(10265), 1784-1786.

Sari, T., \& Nayir, F. (2020). Pandemi Donemi Egitim: Sorunlar ve Firsatlar. Electronic Turkish Studies, 15(4), 959-975.

Sirer, E., (2020), Egitimin Ekran zerinden Teknolojik Donusumunde Pandemi Donemi'nin Etkisi, Uluslararasi Toplum Arastirmalari Dergisi, 16(29), 1989-2018.

Shehata, A., \& Stromback, J. (2014). Mediation of political realities: Media as crucial sources of information. In Mediatization of politics (pp.93-113). Palgrave Macmillan, London. 
Sun, Y., Li, Y., Bao, Y., Meng, S., Sun, Y., Schumann, G., et al., (2020). Brief Report: Increased Addictive Internet and Substance Use Behavior During the COVID19 Pandemic in China. Retrived from https://onlinelibrary.wiley.com/doi/abs/10.1111/ajad.13066

T.C. Saglik Bakanligi. (2020). COVID-19 (SARS-CoV-2 Enfeksiyonu) Rehberi. Ankara.

UNESCO. (2020). COVID-19 Educational disruption and response. Retrived from https://en.unesco.org/covid19/educationresponse

Tso, W. W., Wong, R. S., Tung, K. T., Rao, N., Fu, K. W., Yam, J. C., ... \& Wong, I. C. (2020). Vulnerability and resilience in children during the COVID-19 pandemic. European child \& adolescent psychiatry,1-16. https://doi.org/10.1007/s00787-020-01680-8

van Dijck, J., \& Alinead, D. (2020). Social media and trust in scientific expertise: Debating the covid-19 pandemic in the netherlands. Social Media+Society, 6(4), 1-11.

Vandewater, E. A., Rideout, V. J., Wartella, E. A., Huang, X., Lee, J. H., \& Shim, M. S. (2007). Digital childhood: electronic media and technology use among infants, toddlers, and preschoolers. Pediatrics, 119(5), 1006-1015.

Yao H. (2020). The more exposure to media information about COVID-19, the more distressed you will feel. Brain, behavior, and immunity, 87,167-169.

Yildirim, A. ve Simsek, H. (2011). Sosyal bilimlerde nitel arastirma yontemleri. Ankara: Seckin Yayincilik.

Yuksekogretim Kurulu (YOK) (2020a). Basin aciklamasi, Retrived from https://www.yok. gov.tr/Sayfalar/Haberler/2020/,

Yuksekogretim Kurulu (YOK) (2020b). Basin aciklamasi, Retrived from https://www.yok. gov.tr/Sayfalar/Haberler/2020/,

Xiong, J., Lipsitz, O., Nasri, F., Lui, L. M., Gill, H., Phan, L., ... \& McIntyre, R. S. (2020). Impact of COVID-19 pandemic on mental health in the general population: A systematic review. Journal of affective disorders, 277(2020), 55-64.

Wagner, K. D. (2020). Addressing the experience of children and adolescents during the COVID19 pandemic. The Journal of clinical psychiatry, 81(3), 1-13.

Watson, A. (2020). Coronavirus impact: global in-home media consumption by country 2020 Statista. Retrived from https://www.statista.com/statistics/1106498/home-mediaconsumption-coronavirus-world wide-by-country/.

Wilder-Smith, A. \& Freedman, D. O. (2020). Isolation, quarantine, social distancing and community containment: pivotal role for old-style public health measures in the novel coronavirus (2019-nCoV) outbreak. Journal of travel medicine, 27(2), 1-4.

Wilson, C. (2014). Interview Techniques for UX Practitioners. Elsevier Inc.

World Health Organization, (2020a). Mental health and psychosocial considerations during the COVID-19 outbreak. Retrived from

https://apps.who.int/iris/bitstream/handle/10665/331490/WHO-2019-nCoVMentalHealth-2020.1-eng.pdf

World Health Organization, (2020b). Infection prevention and control health-care facility response for COVID-19. Retrived from https://vk.lovebus.cc/a3651/14-33/mbbdynughz/iris/bitstream/handle/10665/336255/YIN-6843-hBuXIBD_mddqddaqhz-HJB-6868.1-eng.pdf?sequence $=1$ \&isAllowed $=y$

\section{Biographical notes:}

Servet KARDEŞ, Van Yüzüncü Yıl University(http://www.yyu.edu.tr/english/) Assistant Professor, Special Education Department, Special education \#65100. Master degree: Hacettepe University, Preschool Education, Ankara. (2011-2013). Phd: Areas of expertise: preschool education, refugees, media and social emotional development 
Cansu DOKUMACI, graduate student at Van Yüzüncü Yıl University Educational Sciences Enstitute and preschool teacher in MoNE. Areas of expertise : preschool education, media and social emotional development. Preschool Education, Hacettepe University, Ankara (20142018). 